\title{
CERTAIN ASPECTS OF QUALITY IN EDUCATION MANAGEMENT
}

\author{
UDC: $005.6: 371$ \\ Review \\ Doloris BEŠIĆ ${ }^{1}$, Vladimir RADOVANOVIĆ ${ }^{2}$, Snežana BEŠIĆ ${ }^{3}$, Cariša BEŠIĆ \\ ${ }^{1}$ Univerzitet "Union - Nikola Tesla", Faculty of Business Studies and Law, 11070 Novi Beograd, Staro sajmište 29, \\ Republic of Serbia \\ ${ }^{2}$ University of Kragujevac, Faculty of technical science, 32000 Čačak, 65 Svetog Save, Republic of Serbia \\ ${ }^{3}$ High Railway School of Professional Studies, 11000 Belgrade, Zdravka Čelara 14, Republic of Serbia \\ ${ }^{4}$ University of Kragujevac, Faculty of technical science, 32000 Čačak, 65 Svetog Save, Republic of Serbia \\ E-mail: carisa.besic@ftn.kg.ac.rs
}

Paper received: 24.11.2015.; Paper accepted: 02.12.2015.

\begin{abstract}
Today we witness the daily expansion of scientific knowledge, as well as the technological advancement. Simultaneously, the development of technology in education follows. In developing of the modern society the following aspects take part: knowledge, people who know how to apply this knowledge, orientation of business systems and society in a lifelong learning and development. Furthermore, management is a universal activity whose basic sources are knowledge, work culture and business ethics, and the target function is survival, growth and development as well as innovation. The combination of traditional and online learning, or so called, hybrid learning, marked the last decade and has provided teachers with the opportunity to apply advanced technology in the classroom. Classical or traditional education methods are nowadays largely supported, or are completely replaced with new scientific tools and methods that are based on the active use of information and communication technologies. The aim of this paper is to highlight the numerous advantages of new technologies in modern teaching and management.
\end{abstract}

Keywords: education managemnt, quality, information and communication technology, innovation.

\section{INTRODUCTION}

Distance learning is certainly not a new concept in education and dates from the 19th century. At that time, the exchange of literature and the necessary teaching materials, as well as communication between students and teachers were done by mail. In time, technology has progressed and a system of distance learning has developed. Compared with distance learning at the end of the $80 \mathrm{~s}$ the appearance of personal computers and Internet development has resulted in introduction of electronic education. We can say that e-learning is a relatively new system in education. Its wider application of e-learning experiences around 1996 when the technical possibilities for the application of this method of learning were created. Also, in the $90 \mathrm{~s}$ there were formed and centralized the Learning Management Systems (LMS), which are used to monitor individual student progress, implementation of video conferences that are of great importance especially when it comes to the exchange of scientific knowledge in different spheres of education.

Development and human labor are the categories that complement, and separately do not mean anything. Care and development of human resources can be achieved everywhere where there are employees who need new knowledge and quality, and permanent organization of educational process in the business system.

Globalization as universal process deals with all aspects of society, it demolishes borders and establishes new connections and relationships by creating conditions for a faster and more efficient exchange of people, capital, goods, services, money, information and knowledge. Globalization of knowledge can be understood as growth, development and exchange of knowledge between different economic entities on a global basis. 


\section{QUALITY OF MANAGEMENT IN EDUCATION}

Management in education is extremely complex and integrated knowledge of various scientific disciplines of business management processes and people in education. However, management is not a modern scientific discipline but rather the art based on responsibility and different but interrelated knowledge skills (Weick \& Browning, 1986). These skills come from a range of scientific disciplines: economics, education, educational rights, educational technology, organization, staffing, ergonomics, communication, computer science, education science, geography, demographics, occupational medicine, psychology, ethics, aesthetics, sociology and anthropology. Of course, management education is not merely the sum of these different skills. In educational practice problems do not occur as a sociological, psychological, pedagogical, economic, etc., but manifest themselves as "alive and vivid configuration" of different knowledge skills and as life-like complex process whose understanding and management reacquire different but inter-related knowledge skills.

Management in education is defined as coordination of human, physical and financial resources in the activities of education to achieve the goals set forth in state, local and school educational policies, legislation and systemic concepts and projections for development of education. It includes management of the entire activity of education, management of educational institutions, conduct educational and other staff in educational institutions, internal development and organization of school work process. Management in education at the same time refers to different areas of expertise, scientific discipline, profession and function. It is possible to speak about management in education in a broader sense, as administration and management of the overall educational activities (educational management), but also in the narrow sense, as leadership and management of the school and at work as managers of educational institutions (school management).

The goal of management in education is to achieve the best results by using the human, financial and material resources, which are available. The first and main goal is to take care of human resources (students, teachers, parents and other partners). The second objective is the management of knowledge (knowledge development of children, education of teachers, parents and others, and the provision of providing educational services, etc.). One of the goals is also the enrichment of the above potential (to create added educational value). Management in education would not be completely functional without ethical management. Therefore, the development of values (the man as a screen, the user and the creator of values) is referred to as the third goal of the educational management. From these objectives derive the three basic components of educational management. Therefore, it is made up of elements of knowledge management, human resources management and ethical management.

\section{INFORMATION TECHNOLOGY IN CONTEMPORARY EDUCATION MANAGEMENT}

"E-learning is any form of learning, teaching or education which is supported by the use of computer technology, especially computer networks based on Internet technologies." (Simović \& Čukanović-Karavidić, 2010)

"E-learning is interactive and two-way process between teachers and students with the help of electronic media with the emphasis on the process of teaching while the media are only the tool which completes the process." (Simović \& Čukanović-Karavidić, 2010)

Essentially e-learning is the term used to refer to electronic-assisted learning as any form of education in which educational content is delivered in electronic form. Electronic education is that education that uses information and communication technology (ICT) in order to improve the teaching process (Petrović, 2009). When we talk about e-learning we do not refer only to implementation of the educational process from a distance, or to mere physical separation of the participants of this process, but actually we have in mind that e-learning takes place as part of, or complement to classical education. Consequently, we can see that e-learning is divided into two groups - mixed or hybrid learning (hybrid learning of the mix-mode, blended learning) and "pure" e-learning. The mixed or hybrid learning is actually a combination of classic classroom and teaching with the help of information and communication technologies, while "pure" eLearning implies a form of learning where students learn independently and on line.

E-learning is a process that cannot be activated at once. It is accepted in four cycles (Zemsky \& Massy, 2004): 
I. The first cycle of e-learning refers to the improvement of the traditional program with the help of new materials and resources, with the method of instruction that does not change. Classic examples are the use of PowerPoint presentations in classes, use of the Internet for research, communication via email.

II. The second cycle of integration of e-learning in education involves the use of new resources to manage the process of teaching. Examples of such resources are the software for the distribution of teaching materials and tests that can provide electronic communication, processing and tracking of learning outcomes and the like.

III. The third cycle is a cycle in which the real, shared and reused reusable learning objects are made by a certain standard and which may be a simple form of text documents, or technological content and complex interactive simulations.

IV. The fourth and last cycle is characterized by the emergence of new configurations of which are created when teachers and educational institutions completely transform the way of learning and their education in order to take full advantage of new technologies.

A synonym for modern education today is elearning, but the introduction of this system of education is not a simple process. For the effective implementation of e-learning in the educational process it is necessary to fulfill three basic conditions: the existence of appropriate standards, strategic equipment of educational institutions for the introduction of ICT in the education process and support e-learning. A very small number of universities and faculties in Serbia can be proud of the fact that their students have the possibility of distance learning. Large part of e-learning programs in Serbia boil down to mixed or hybrid, learning or conversion of traditional teaching materials (textbooks, workbooks etc.) in the digitized format and create PowerPoint presentations.

\section{THE ADVANTAGES OF E-LEARNING IN EDUCATION}

E-learning has many advantages such as:

- Individual approach to students and acceptance of different learning styles;

- A higher level of interaction between professors and students;

- Better quality of education and increase opportunities adoption records, fostering analytical thinking, synthesis of acquired knowledge and independence of students;

- Inclusion of students with different profiles, as well as customize content for teaching individual pupils;

- Easy and available vocational training or retraining;

- Flexibility in terms of space and time, which makes education accessible to all students anytime, anywhere;

- Encouragement of students to work in teams on various projects;

- The use of various interactive content and media for learning; and

- The use of different technologies in practice.

The introduction of e-learning in an environment is not an instant process. On the contrary, in order to efficiently introduce e-learning in teaching we have to meet some basic requirements. Three basic preconditions for the introduction of e-learning in the classroom are: existence of appropriate standards; strategic equipment of educational institutions for the introduction of information and communication technologies in the educational process; and support to e-learning (Fallon \& Brown, 2002).

\section{LEARNING SYSTEMS AND QUALITY IN EDUCATION MANAGEMENT}

"The amounts of knowledge in modern society are enormous, which is why the important element is to enable the student to independently learn and applies them, but to insist on memorizing facts which the individual is able to apply in practice "(Novković, 2011).

As mentioned above, the interaction between students and teachers as well as the degree of motivation is of great importance for effective learning. Also, the factor which significantly affects the improvement of interaction and raises the level of motivation is the learning environment. The key to success lies in a stimulating learning environment.

The main task of stimulating learning environments, both in the classroom and online, is to enable the transfer of knowledge from professor to student, as well as the ability to communicate between them with the aim of improving knowledge. Learning in a group of students and their cooperation in learning are parts of a stimulating environment for learning (Milosavljević, 2006). 
With the aim of developing a stimulating learning environment on the computer network, special software has been designed that allows the creation and storage of multimedia educational materials in electronic form. Also, with the help of this software the individual delivery of multimedia educational materials in electronic form is enabled, as well as the examination of students. It is characteristic that all the learning outcomes of students are recorded in the database and thus monitored and analyzed in the learning process. Communication between student-teacher is done electronically, or via e-mail or through forums.

Closed and controlled system which in this way forms a stimulating environment is called a learning management system - Learning Management System (LMS). The task of LMS is to enable: delivery of learning content; tracking of learning content; reporting and administration of learning content; monitoring the progress of students; and mutual communication between the student-mentor and student-student.

The most important functions of LMS are: checkin and checkout; testing; management process; user functions; monitoring and tracking; and administrative functions. Learning Management Systems offer the possibility of achieving different aspects of cooperation during the learning process.

\section{CONCLUSION}

The changes are characteristic of the twenty-first century. They are deep and fast, they affect all areas of work and life. Changes in the environment have a crucial impact on shaping the future goals of the undertakings, giving them a new feature of the new approach, which is the strategic approach. New environment and new social laws are the infrastructure for new economic activity, which requires the development of the education system and the quality of human resources through major investments in the development of innovation and new business entities with respect and leveraging global standards of good management.

Numerous attitudes, approaches and definitions of education can still be divided into two groups. On one hand there are those who see modern education as a contribution to the achievement of social life and fundamental social process maintenance and the progress of mankind, as well as continuity of culture. While on the other hand, the modern education is also considered to be a key factor in economic development and knowledge of who depend on all the other processes.

Along with the change in educational process, the role of teachers, as well as students in education changes. Overemphasized role of teachers lecturing is replaced by the role of teachers who are at the same time organizers and advisors, and motivators and strategists. The introduction of information and communication technologies and the LMS system in the process of teaching has proven to be an effective way of controlling, regulating, and course management. This system of education enables learning through constant feedback, or feedback, which has a strong motivational power for which we can say that is the basis of a system of evaluation and assessment of student work. The use of ICT in teaching affect the change of teaching forms and methods in order to overcome the disadvantages of the classical realization of teaching and educational process to rise to a higher or better level. However, it should be borne in mind that the role of technology is not to replace teachers or professors, but to enable them to better and more effectively achieve their educational goals.

\section{REFERENCES}

Fallon, C., \& Brown, S. (2002). E-learning standards, A Guide to Purchasing, Developing, and Deploying Standards-Conformant E-Learning.

Milosavljević, M. (2006). Partner u učenju, Elektronski časopis za nastavnike, from https://pilcasopis.wordpress.com/

Novković, A. (2011). Inovativni modeli rada $u$ oblikovanju nastavnih sadržaja za obrazovni računarski softver. Paper presented at the VI Simpozijum sa međunarodnim učešćem Tehnologija, informatika i obrazovanje-za društvo učenja i znanja TIO6, Čačak

Petrović, M. (2009). Elektronsko učenje podržano Internet tehnologijama (geneza, pojam i predviđaja razvoja). Norma, XIV(3), 263-280.

Weick, K. E., \& Browning, L. D. (1986). Argument and narration in organizational communication. Journal of Management, 12, 243-259.

Simović, D., \& Čukanović-Karavidić, M. (2010). Eobrazovanje. Paper presented at the Tehnika i informatika u obrazovanju, 3. Internacionalna konferencija, Čačak

Zemsky, R., \& Massy, W. F. (2004). Thwarted Innovation: What Happened to e-learning and Why? A Final Report for The Weatherstation Project of The Learning Alliance at the University of Pennsylvania in cooperation with the Thomson Corporation. 